Bangladesh J. Plant Taxon. 22(2): 87-98, 2015 (December)

\title{
NUMERICAL TAXONOMY OF ABELMOSCHUS MEDIK. (MALVACEAE) IN INDIA
}

\author{
PRAVIN PATIL ${ }^{1}$, SHRIKANT SUTAR ${ }^{2}$, SURENDRA KUMAR MALIK, JOSEPH JOHN ${ }^{3}$, \\ SHRIRANG YADAV ${ }^{2}$ AND KANGILA VENKATARAMAN BHAT \\ National Bureau of Plant Genetic Resources, Pusa Campus, \\ New Delhi 110012, India
}

Keywords: Abelmoschus; Phenetics; Species relationships; India.

\begin{abstract}
In the present study, numerical taxonomy approach has been used for the first time to access the taxonomy and species relationships of Abelmoschus. Sixteen Abelmoschus taxa were subjected to cluster analysis using 52 diagnostic characters related to root, stem, leaf, flower, fruit and seed. In this analysis, the first six principal components (PCs) accounted for the total variance of $79.22 \%$. Similarity values for all 17 operational taxonomic units (OTUs) ranged from 0.18 to 0.82 with an average of 0.34 . Abelmoschus sagittifolius showed maximum similarity value of 0.82 with $A$. moschatus subsp. tuberosus. On the other hand, minimum similarity values $(0.18)$ were observed between $A$. tuberculatus and A. moschatus subsp. tuberosus, A. tuberculatus and A. sagittifolius, A. palianus and A. moschatus subsp. tuberosus, and A. palianus and A. sagittifolius. Neighbour joining (NJ) cluster analysis clearly discriminated 17 OTUs into four major clusters. The present study also validates the utility of morphometric analysis of Abelmoschus with respect to the taxonomy and species relationships.
\end{abstract}

\section{Introduction}

Over the years, taxonomy has found important practical applications in various fields of science such as theoretical and applied biology including agriculture, evolutionary study, forestry, public health, biodiversity management and environmental issues (Godfray, 2002). Adanson (1763) proposed that classification should be based on characters covering all aspects of plant such as leaf, flower, fruit, seed, and each character should be given equal importance. As a consequence, a mathematical approach has been established by taxonomists called Numerical Taxonomy (Sokal and Sneath, 1963). Morphological data are considered significant in systematics because variation exhibited by morphological traits is supposed to be categorized by gaps between taxa which reflect their evolutionary arrangement emerged through morphological changes (Otte and Endler, 1989).

Taxonomy of Abelmoschus Medik. has a complex history with uncertainty in the generic status and composition of the genus as well as the species concept applied within the genus. The taxonomic treatment for some species of Abelmoschus is not consistent. Abelmoschus manihot (L.) Medik. and A. moschatus Medik. are the most polymorphic species (Hamon and Charrier, 1983). Hochreutiner (1924) described 14 species of Abelmoschus, in which A. moschatus and A. manihot constitute several varieties. However, Sivarajan and Pradeep (1996) did not consider infra-specific classification of A. manihot produced by Van Borssum-Waalkes (1966). Paul and Nayar (1988) and Paul (1993) therefore treated A. manihot as a single species without any infra-specific classification. Bates (1968) also suggested that all subspecies and varieties of A. manihot should

\footnotetext{
${ }^{1}$ Corresponding author. Email: pravin.pati199@gmail.com

${ }^{2}$ Botany Department, Shivaji University, Kolhapur 416004, India.

${ }^{3}$ National Bureau of Plant Genetic Resources Regional Station, KAU PO, Thrissur 680656, India.
} 
be compressed in one group. Later, Vredebregt (1991) pointed out that A. manihot subsp. manihot, A. manihot subsp. tetraphyllus var. tetraphyllus and A. manihot subsp. tetraphyllus var. pungens complex lack discrete species boundaries among them, which further contradicts Hochreutiner (1900), Van Borssum-Waalkes (1966), Paul and Nayar (1988) and Paul (1993). Infraspecific taxonomy of A. moschatus is also a matter of debate as many subspecies and varieties have been recognized by Masters (1874), Hochreutiner (1900) and Van Borssum-Waalkes (1966).

Wild species of Abelmoschus comprise still larger unexplored variability, not even 2-3\% of them have been studied beyond recognizing them as valuable reservoirs of untagged genes of agronomically useful traits (Sandhu et al., 1974). Therefore, a thorough and robust hypothesis is urgently needed on morphological variation and species relationships among all taxonomically valid species of Abelmoschus which may provide the species-wise perspective that will be used in okra [A. esculentus (L.) Moench.] breeding strategies and effective germplasm management. The main objective of this study were to examine the morphological variation related to root, stem, leaf, flower, fruit and seed characters of Abelmoschus taxa by means of numerical taxonomy in order to resolve their relationships.

\section{Materials and Methods}

Taxon sampling and taxonomic treatment

On the basis of distribution data obtained from literature survey, several field trips were undertaken during 2010-2012 to collect and study different taxa of Abelmoschus occurring in India (Table 1). Confirmation of collected specimens was ensured with the help of information gathered from floras, published reports (Van Borssum-Waalkes, 1966; Paul and Nayar, 1988; Sivarajan and Pradeep, 1996) and the herbarium specimens. A standard procedure of using herbarium material was applied (Edlley et al., 2012). Morphological characters of plants related to root, stem, leaf, flower, fruit and seed were described from their natural habitats, to avoid any ambiguity in the characters due to environmental effect. Seed related characters were taken from Patil et al. (2015).

\section{Character selection and data analysis}

Species and in some cases their populations were used as operational taxonomic units (OTUs) for numerical taxonomy based on morphological data. Characters selected for morphological description of Abelmoschus species were those reported by Bisht et al. (1993, 1995), Sivarajan and Pradeep (1996) and based on field observations. A total 52 diagnostic characters related to habit, stem, leaf, flower, fruit and seed were chosen and scored for each OTU (Table 2).

The characters were converted into binary states and multi-states (interval) code. Standardization to $\mu=0$ and $\sigma=1$ of morphological data were done based on YBAR option with the software NTSYSpc ver. 2.10e (Rohlf, 1992). Neighbour joining tree was constructed using euclidean distance with the same software. Principal components (PCs) analysis was performed to analyze non-hierarchical relationship among the OTUs. This analysis was executed by calculating the eigenvectors and eigen values from Eigen programme in the NTSYS software. Morphometric analyses of quantitative data related to leaf, flower and fruit were done using SPSS version 11.5 for Windows.

\section{Results}

\section{Morphological observations}

Morphological evaluation of Abelmoschus species demonstrated that characters related to root, pubescent stem, leaf, flower, fruit and seed were significantly different between species. Root of A. enbeepeegearense John et al., A. crinitus Wall. and A. sagittifolius (Kurz.) Merr. ss., was 
tuberous, while rest of the species was non-tuberous. Abelmoschus enbeepeegearense, A. crinitus, A. manihot (L.) Medik. subsp. tetraphyllus (Roxb. ex Hornem.) Borss. var. pungens (Roxb.) Hochr. and A. moschatus Medik. subsp. moschatus, had conspicuous stem, while rest of the species had glabrous stem. Flowers of A. ficulneus and A. angulosus var. angulosus had white corolla, while A. angulosus var. purpureus had pink corolla. On the other hand, rest of the species

Table 1. Studied taxa of Abelmoschus along with their codes, accession numbers, places of collection (latitude/longitude) and altitude.

\begin{tabular}{|c|c|c|c|c|c|}
\hline $\begin{array}{l}\text { Sl. } \\
\text { No. }\end{array}$ & Taxon & Code & $\begin{array}{l}\text { Accession/ } \\
\text { collector no. }\end{array}$ & $\begin{array}{l}\text { Place of collection } \\
\text { (Latitude/Longitude) }\end{array}$ & $\begin{array}{l}\text { Altitude } \\
(\mathrm{m})\end{array}$ \\
\hline 1. & $\begin{array}{l}\text { Abelmoschus esculentus (L.) } \\
\text { Moench. }\end{array}$ & AES & Var. AA & NA & NA \\
\hline 2. & A. caillei (A. Chev.) Stevels & ACA & NMB2924 & $\begin{array}{l}\mathrm{N} 5^{\circ} 26.860^{\prime} / \mathrm{E} 20^{\circ} \\
88.221^{\prime}\end{array}$ & 1012 \\
\hline 3. & $\begin{array}{l}\text { A. moschatus Medik. subsp. } \\
\text { moschatus (odourless seed) }\end{array}$ & AMO & EC316073 & NA & NA \\
\hline 4. & $\begin{array}{l}\text { A. moschatus Medik. subsp. } \\
\text { moschatus (musk scented seed) }\end{array}$ & $\mathrm{AMM}$ & IC141056 & $\begin{array}{l}\mathrm{N} 8^{\circ} 38.999^{\prime} / \mathrm{E}^{\circ} 7^{\circ} \\
03.698^{\prime}\end{array}$ & 124 \\
\hline 5. & $\begin{array}{l}\text { A. moschatus Medik. subsp. } \\
\text { tuberosus }\end{array}$ & ATR & IC 324070 & NA & NA \\
\hline 6. & A. sagittifolius (Kurz.) Merr. ss. & ASG & W357 & $\begin{array}{l}\mathrm{N} 19^{\circ} 17.265^{\prime} / \mathrm{E}^{\circ} 7^{\circ} \\
30.977^{\prime}\end{array}$ & 487 \\
\hline 7. & A. tuberculatus Pal \& Singh & ATB & IC550656 & $\begin{array}{l}\mathrm{N} 19^{\circ} 24.909^{\prime} / \mathrm{E}^{\circ} 8^{\circ} \\
03.337^{\prime}\end{array}$ & 432 \\
\hline 8. & A. ficulneus (L.) Wight \&Arn. & AFI & IC141001 & $\begin{array}{l}\mathrm{N} 15^{\circ} 30.040^{\prime} / \mathrm{E}^{\circ} 4^{\circ} \\
59.587^{\prime}\end{array}$ & 644 \\
\hline 9. & A. crinitus Wall. & ACR & N/SS2759 & $\begin{array}{l}\mathrm{N} 19^{\circ} 43.478^{\prime} / \mathrm{E}^{\circ} 8^{\circ} \\
17.201^{\prime}\end{array}$ & 470 \\
\hline 10. & $\begin{array}{l}\text { A. manihot (L.) Medik. subsp. } \\
\text { manihot }\end{array}$ & AMN & TCR2305 & $\begin{array}{l}\mathrm{N} 16^{\circ} 40.857^{\prime} / \mathrm{E}^{\circ} 4^{\circ} \\
12.759^{\prime}\end{array}$ & 569 \\
\hline 11. & $\begin{array}{l}\text { A. manihot (L.) Medik subsp. } \\
\text { tetraphyllus (Roxb. ex Hornem.) } \\
\text { Borss. Waalk. }\end{array}$ & AMT & IC141019 & $\begin{array}{l}\mathrm{N} 23^{\circ} 34.630^{\prime} / \mathrm{E}^{\circ} 8^{\circ} \\
33.261^{\prime}\end{array}$ & 1828 \\
\hline 12. & $\begin{array}{l}\text { A. manihot (L.) Medik. subsp. } \\
\text { tetraphyllus (Roxb. ex Hornem.) } \\
\text { Borss. var. pungens (Roxb.) Hochr. }\end{array}$ & AMP & NMB2933 & $\begin{array}{l}\mathrm{N} 19^{\circ} 11.795^{\prime} / \mathrm{E}^{\circ} 3^{\circ} \\
42.307^{\prime}\end{array}$ & 904 \\
\hline 13. & $\begin{array}{l}\text { A. angulosus var. grandiflorus } \\
\text { Thwaites }\end{array}$ & AAG & IC470751 & $\begin{array}{l}\mathrm{N} 12^{\circ} 26.429^{\prime} / \mathrm{E}^{\circ} 5^{\circ} \\
39.666^{\prime}\end{array}$ & 694 \\
\hline 14. & $\begin{array}{l}\text { A. angulosus var. purpureus } \\
\text { Thwaites }\end{array}$ & AAP & AP1 & $\begin{array}{l}\mathrm{N} 13^{\circ} 25.799^{\prime} / \mathrm{E}^{\circ} 5^{\circ} \\
44.921^{\prime}\end{array}$ & 1606 \\
\hline 15. & $\begin{array}{l}\text { A. angulosus var. angulosus Sivrajan } \\
\text { \& Pradeep }\end{array}$ & AAA & AA1 & NA & NA \\
\hline 16. & A. enbeepeegearense John et al. & AEN & JRN/09/25 & NA & NA \\
\hline 17. & A. palianus Sutar et al. & APA & SUA54 & NA & NA \\
\hline
\end{tabular}

$* \mathrm{NA}=$ not available 
Table 2. Description of 52 morphological characters used in the cluster analysis of 16 taxa of Abelmoschus.

\begin{tabular}{|c|c|c|c|}
\hline $\begin{array}{l}\text { Sl. } \\
\text { No. }\end{array}$ & Character & Code & Description/Value \\
\hline & Habit: & & \\
\hline \multirow[t]{2}{*}{1} & Growth habit & GRH & erect (0) medium (1) procumbent (2) \\
\hline & Root: & & \\
\hline \multirow[t]{2}{*}{2} & Root type & ROT & non-tuberous $(0)$ tuberous $(1)$ \\
\hline & Stem: & & \\
\hline 3 & Branching habit & BRH & $\begin{array}{l}\text { non-branched ( } 0 \text { ) branched only at base (1) branched } \\
\text { evenly (2) branched only at top (3) }\end{array}$ \\
\hline 4 & Stem pubescence & STP & glabrous (0) slight (1) conspicuous (2) \\
\hline \multirow[t]{2}{*}{5} & Stipule shape & STS & $\begin{array}{l}\text { long linear (0) linear lanceolate (1) triangular (2) short } \\
\text { linear (3) }\end{array}$ \\
\hline & Leaf: & & \\
\hline 6 & Leaf colour & LEC & $\begin{array}{l}\text { green (0) green with red veins (1) dark green (2) light green } \\
(3)\end{array}$ \\
\hline 7 & Leaf length & LEL & in $\mathrm{cm}$ \\
\hline 8 & Leaf width & LEW & in $\mathrm{cm}$ \\
\hline 9 & Leaf length : width ratio & LLW & - \\
\hline 10 & No. of lobes & NLN & $5(0)$ more than $5(1)$ less than $5(2)$ \\
\hline 11 & Leaf texture & LTX & glabrous (0) slight (1) conspicuous (2) wooly (3) \\
\hline \multirow[t]{2}{*}{12} & Leaf margin & LMR & $\begin{array}{l}\text { crenate (0) dentate (1) undulate (2) entire (3) serrate (4) } \\
\text { serrulate (5) }\end{array}$ \\
\hline & Flower: & & \\
\hline 13 & Flower stalk & FST & straight (0) drooping (1) \\
\hline 14 & Pedicel length & PDL & in $\mathrm{cm}$ \\
\hline 15 & No. of epicalyx segment & NES & in no. \\
\hline 16 & $\begin{array}{l}\text { Shape of epicalyx } \\
\text { segment }\end{array}$ & SHE & $\begin{array}{l}\text { linear (0) lanceolate (1) triangular (2) ovate (3) broadly } \\
\text { lanceolate (4) deltoid (5) }\end{array}$ \\
\hline 17 & Persistence of epicalyx & PEE & $\begin{array}{l}\text { caducous (0) partially persistent (up to seven days) (1) } \\
\text { persistent (2) }\end{array}$ \\
\hline 18 & Flower length & FLL & in $\mathrm{cm}$ \\
\hline 19 & Flower diameter & FDM & in $\mathrm{cm}$ \\
\hline 20 & $\begin{array}{l}\text { Flower length : } \\
\text { diameter ratio }\end{array}$ & FLD & - \\
\hline 21 & $\begin{array}{l}\text { Flower length : pedicel } \\
\text { length ratio }\end{array}$ & FLP & - \\
\hline 22 & No. of petals & NPT & $5(0)$ more than $5(1)$ \\
\hline 23 & Petal colour & PTC & $\begin{array}{l}\text { yellow (0) light yellow (1) dark yellow (2) red (3) pink (4) } \\
\text { white (5) }\end{array}$ \\
\hline 24 & Length of style & LST & in $\mathrm{cm}$ \\
\hline 25 & No. of stigma lobes & NSL & $5(0) 6$ to $8(1)$ \\
\hline \multirow[t]{2}{*}{26} & Stigma colour & $\mathrm{SCO}$ & red (0) dark red (1) light red (2) white (3) pink (4) \\
\hline & Fruit: & & \\
\hline 27 & Fruit colour & $\mathrm{FCO}$ & green (0) dark green (1) yellow green (2) \\
\hline
\end{tabular}




\begin{tabular}{|c|c|c|c|}
\hline $\begin{array}{l}\text { Sl. } \\
\text { No. }\end{array}$ & Character & Code & Description/Value \\
\hline 28 & Fruit shape & FSH & $\begin{array}{l}\text { lanceolate (0) ovoid (1) lanceolate-ovoid (2) broadly ovoid } \\
\text { (3) widely elliptic (4) }\end{array}$ \\
\hline 29 & Fruit beak & FBE & non-beaked (0) beaked ( 1 ) \\
\hline 30 & Fruit length & FRL & in $\mathrm{cm}$ \\
\hline 31 & Fruit width & FRW & in $\mathrm{cm}$ \\
\hline 32 & Fruit length : width ratio & FLW & - \\
\hline 33 & Fruit pubescence & FPB & $\begin{array}{l}\text { tomentose }(0) \text { glandular hairy (1) soft strigulose (2) densely } \\
\text { hispid (3) hirsute (4) tuberculate hairy (5) }\end{array}$ \\
\hline 34 & Fruit tuberculation & FTB & non-tuberculate $(0)$ tuberculate $(1)$ \\
\hline 35 & Fruit dehiscence & FDH & laterally (0) apically (1) \\
\hline & $\begin{array}{l}\text { Seed: a. macro- } \\
\text { morphology }\end{array}$ & & \\
\hline 36 & Seed odour & SOD & odourless (0) musk scented (1) \\
\hline 37 & Seed size & SDS & large (0) medium (1) small (2) \\
\hline 38 & Seed shape & SSH & obovate (0) globose (1) reniform (2) sub-reniform (3) \\
\hline 39 & Seed colour & $\mathrm{SCO}$ & dark brown (0) brown (1) greenish (2) blackish (3) \\
\hline 40 & Seed texture & STX & glabrous (0) pubescent (1) \\
\hline 41 & Hilum position & HLP & terminal (0) sub-terminal (1) \\
\hline 42 & $\begin{array}{l}\text { Hilum shape } \\
\text { b. micro-morphology }\end{array}$ & HLS & ovate ( 0 ) broad ovate (1) triangular (2) round (3) \\
\hline 43 & Trichome & TRC & absent (0) present (1) \\
\hline 44 & Trichome density & TRD & sparse (0) dense (1) \\
\hline 45 & Trichome type & TRT & spiral (0) non-spiral (1) \\
\hline 46 & Seed sculpture & $\mathrm{SSC}$ & reticulate $(0)$ reticulate-foveate (1) \\
\hline 47 & Epidermal cell shape & ECS & polygonal (0) tetra-hexagonal (1) pentagonal-hexagonal (2) \\
\hline 48 & Anticlinal wall shape & AWS & undulate $(0)$ striate $(1)$ \\
\hline 49 & Anticlinal wall thickness & AWT & thin $(0)$ thick $(1)$ \\
\hline 50 & Anticlinal wall level & AWL & raised (0) grooved (1) \\
\hline 51 & Periclinal wall level & PWL & convex (0) concave (1) flat (2) \\
\hline 52 & Periclinal wall texture & PWT & tuberculate (0) smooth (1) wavy (2) not noticeable (3) \\
\hline
\end{tabular}

had yellow corolla. Abelmoschus angulosus var. grandiflorus Thwaites, A. angulosus var. angulosus Thwaites, A. angulosus var. purpureus Thwaites, A. ficulneus (L.) Wight \& Arn., and A. sagittifolius had ovoid fruits, while A. palianus fruits were broadly ovoid. Fruits dehiscence was apically in A. ficulneus, A. tuberculatus $\mathrm{Pal} \&$ Singh, A. manihot, A. palianus Sutar et al. and A. crinitus, while rest of the species laterally dehiscence. Seeds of A. moschatus subsp. moschatus had musk scent, and the remaining species were odourless.

Using the seed morphological characters, the studied taxa of the Abelmoschus revealed two basic types of seeds i.e., Type I: Seeds with deciduous trichomes and Type II: Seeds with persistent trichomes. Abelmoschus esculentus, A. caillei, A. crinitus, A. moschatus subsp. moschatus, A. moschatus subsp. tuberosus and A. enbeepeegearense belong to the Type I. In contrast, Type II comprises A. ficulneus, A. tuberculatus and A. manihot subsp. tetraphyllus var. pungens, A. manihot subsp. manihot, A. manihot subsp. tetraphyllus var. tetraphyllus, A. angulosus var. grandiflorus, A. angulosus var. purpureus, A. angulosus var. angulosus and A. palianus. 
Numerical taxonomic analysis

The ratio of leaf length to leaf width and flower length to flower diameter did not show variation among the studied OTUs. Pearson's correlation analysis was done to determine the correlation among leaf, flower and fruit characters (Table 3). The highest positive correlation value ( $r \mathrm{p})$ was observed between FDM to FLL (0.878) followed by LEW to LEL (0.862) and FRL to LEL (0.816) at 0.01 level of significance. On the other hand, the lowest positive correlation value was observed between PDL to LEL (0.041) followed by FLP to LEL (0.052) and FRW to FLD (0.070). However, negative correlation was also observed between LLW to LEW (-0.437), FRW to FLP (-0.538) and FLP to PDL (-0.741).

Analysis of the $52 \times 17$ correlation matrix data set resulted in 14 eigenvectors (PCs). Out of 14 PCs, first six PCs were retained because they had eigenvalues of equal or higher than 1. For each PC, a component loading of more than 0.05 was considered as being significant. In this analysis, the first six PCs $(\mathrm{PC} 1=23.48 \%, \mathrm{PC} 2=19.34 \%, \mathrm{PC} 3=12.13 \%, \mathrm{PC} 4=10.28 \%, \mathrm{PC} 5=7.47 \%$ and PC6 $=6.52 \%$ ) accounted for the total variance of $79.22 \%$ differentiating the 17 OTUs. The first axis (PC-1) was highly influenced by STS, SHE, NSL, FTB, SOD, SCO and HLS, and defined $23.48 \%$ of the overall variance. These characters show considerable significant values of taxonomic importance with respect to the species differentiation. For the second axis (PC-2), the characters contributing to the total variability were BRH, FCO, FLW, SDS, SOD and HLP with $19.34 \%$ of variance. In the third axis (PC-3), characters such as GRH, LEC, NLN, LMR, NPT, AWL and PWL showed significant value of taxonomic importance to discriminate the 17 OTUs.

Similarity values of all 17 OTUs ranged from 0.18 to 0.82 (Table 4). Abelmoschus sagittifolius showed maximum similarity value of 0.82 with A. moschatus subsp. tuberosus, whereas minimum similarity value (0.18) was observed between $A$. tuberculatus and $A$. moschatus subsp. tuberosus, A. tuberculatus and A. sagittifolius, A. palianus and A. moschatus subsp. tuberosus, and A. palianus and A. sagittifolius. Neighbour joining (NJ) cluster analysis clearly discriminated 17 OTUs producing four major clusters (Fig. 1).

Cluster I: A. esculentus, A. caillei, A. tuberculatus and A. ficulneus

Cluster II: A. moschatus subsp. moschatus (musk scented seed), A. moschatus subsp. moschatus (odourless seed), A. moschatus subsp. tuberosus, A. sagittifolius, A. crinitus, A. enbeepeegearense and $A$. manihot subsp. tetraphyllus var. pungens

Cluster III: A. angulosus var. grandiflorus, A. angulosus var. angulosus, A. angulosus var. purpureus and A. palianus

Cluster IV: A. manihot subsp. manihot and A. manihot var. tetraphyllus

\section{Discussion}

Plant species have been considered as the central units of ecological and evolutionary studies, and therefore, the identification of boundaries among closely related species is an essential target of current systematic studies (Edlley et al., 2012). In this study, morphological variation based on 52 characters (qualitative and quantitative) related to habit, root, stem, leaf, flower, fruit and seed were analyzed, which gave new insights into their potential taxonomic values for the species differentiation in the genus Abelmoschus.

Focusing on the root type in Abelmoschus species the present study revealed that there are only three species, which have tuberous root and others are non-tuberous. The characters such as shape of stipule, number of lobes in leaf, leaf margin, shape and nature of epicalyx segment, petal colour, number of stigma lobe, fruit colour, fruit tuberculation, seed odour, seed colour and seed size significantly contributed to separating the studied taxa and have always been central diagnostic characters in the genus Abelmoschus (Medikus, 1787; Van Borssum-Waalkes, 1966; 


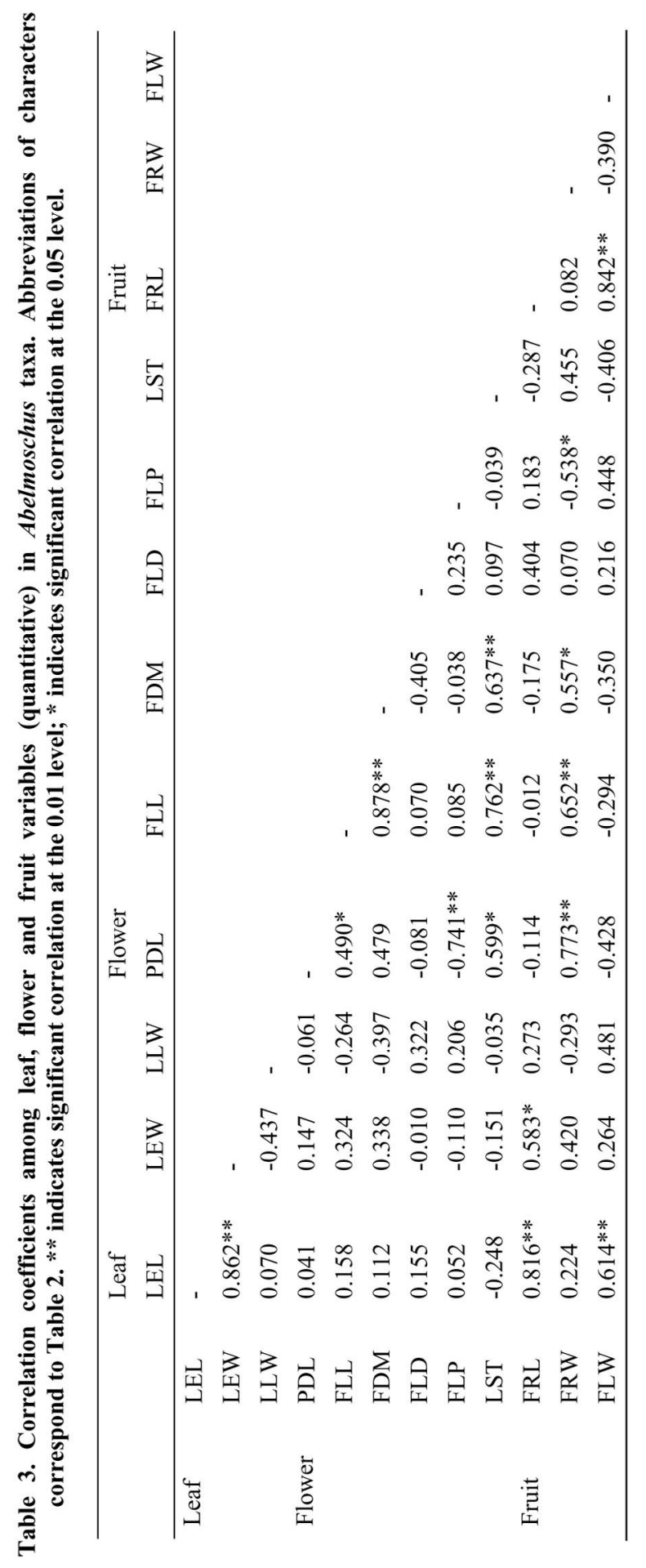




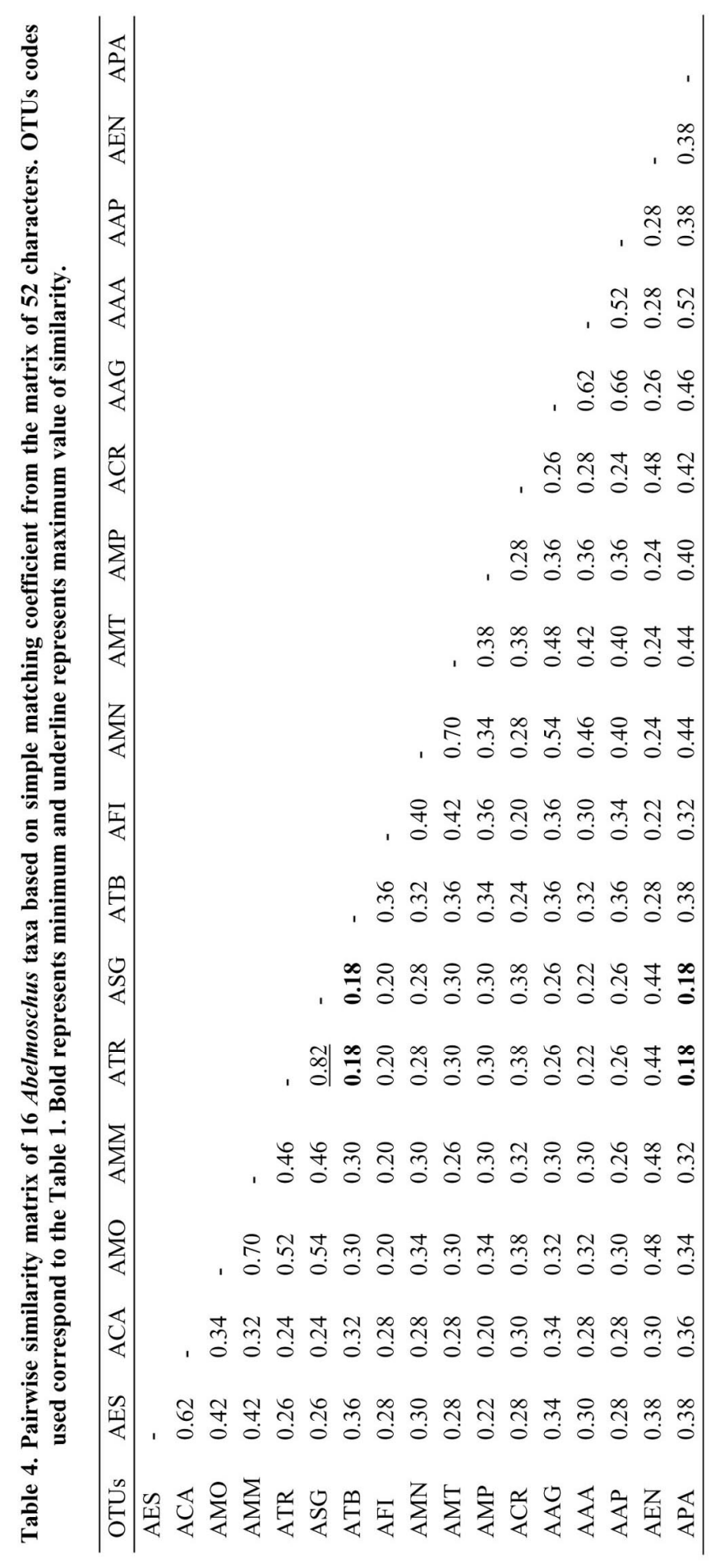




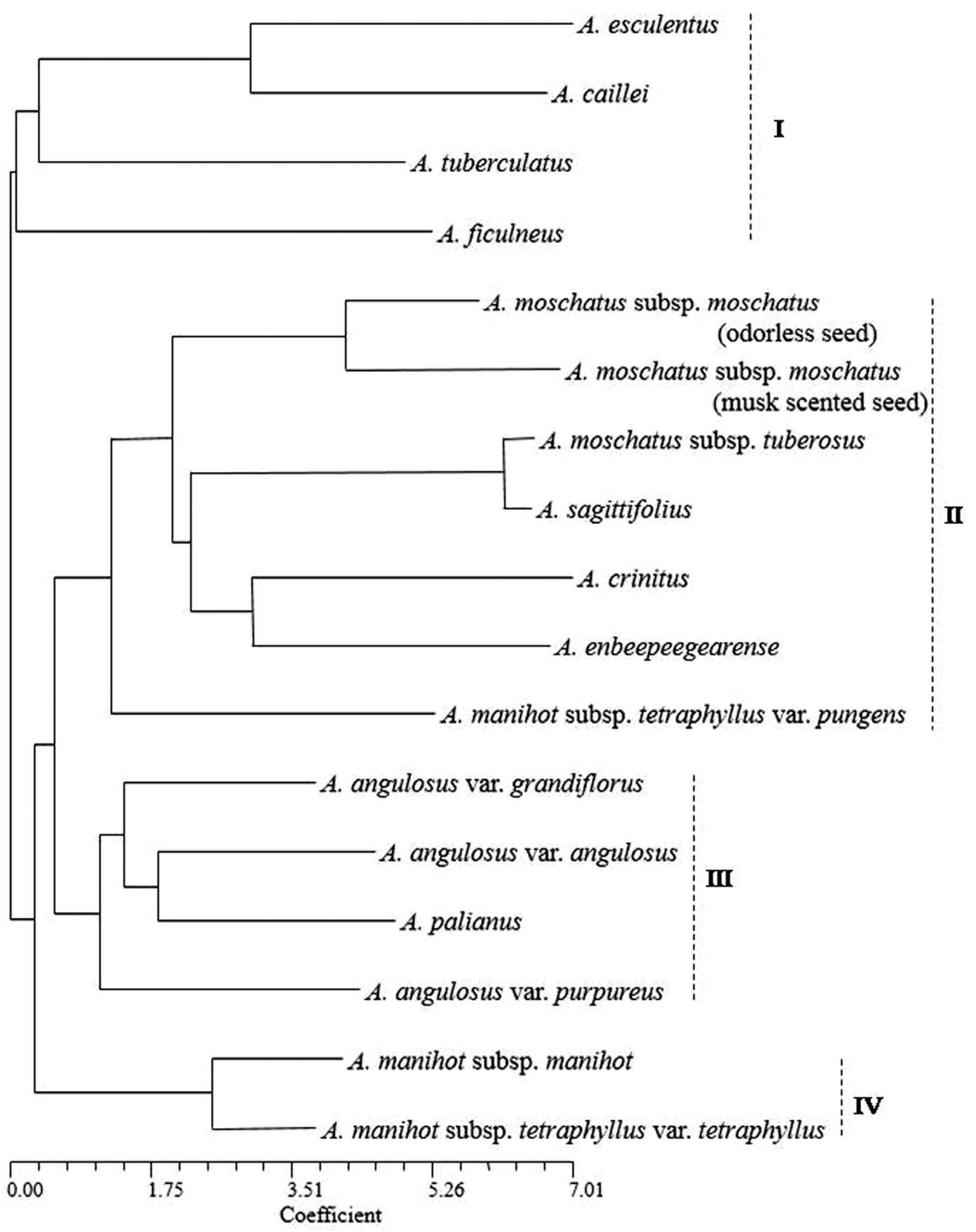

Fig. 1. Dendrogram obtained from neighbour joining (NJ) method showing the relationships of Abelmoschus taxa employed in the study.

Paul and Nayar, 1988; Vredebregt, 1991; Sivarajan and Pradeep, 1996; John et al., 2012; Sutar et al., 2013). The large positive correlation value as observed between leaf length and fruit length, pedicel length and fruit width, flower length and flower diameter were found to be most important and can be useful in a combination for more precise identification of Abelmoschus species. 
In relation to the origin of cultivated okra, A. tuberculatus was found to be closely related to the A. esculentus in NJ tree, which further supports the hypothesis of Masters (1875) and Joshi et al. (1974). On the basis of species relationships as revealed by $\mathrm{NJ}$ tree, it is also assumed that $A$. ficulneus might have contributed to the A. esculentus genome as a second parent. The conspicuous presence of trichome on the seeds of A. tuberculatus is in partial agreement with Van BorssumWaalkes (1966) who treated it as a wild form of $A$. esculentus since it generally grows along the roadsides and grassy slopes. Among the cultivated okra A. esculentus and A. caillei have great similarities in reproductive features. These species generally pose challenge for identification. The results of this study confirmed that cultivated species $A$. esculentus (Asian genotype) and A. caillei (introduced genotype) are morphologically distinct and easy to recognize. RAPD based characterization (Sunday et al., 2008) revealed significant differences between A. esculentus and A. caillei accessions which further confirms our findings about their differentiation.

Owing to the close relationships within the species in Cluster II, we observed some common features, such as seed shape and remnants of trichomes on concentric rows in A. moschatus subsp. moschatus, A. moschatus subsp. tuberosus, A. enbeepeegearense and A. crinitus. These characters are confined to these species only indicating their taxonomically diverse nature. Investigations further revealed the remarkable variations in seed coat patterns of two very close taxa, i.e. $A$. moschatus subsp. tuberosus and A. moschatus subsp. moschatus supporting Bates (1968), who proposed to elevate $A$. moschatus subsp. tuberosus to the specific rank. Taking only taxonomic treatment into consideration, the present study also assumed that A. moschatus subsp. tuberosus and $A$. sagittifolius are not two separate entities but same, since both taxa have tuberous root type and yellow flower. Seed odour was found to be distinguishing characters for the correct identification of A. moschatus subsp. moschatus from other species of Abelmoschus. Another interesting new entity A. enbeepeegearense recently described by John et al. (2012) from the Southern Western Ghats showed intermediate characters (seed shape and seed colour) of $A$. moschatus subsp. moschatus, A. moschatus subsp. tuberosus and A. crinitus. However, seed coat features present in this taxon fully support its elevation as a separate species.

Among the species complex in Abelmoschus, A. manihot has been considered a highly variable taxa. Interestingly, for perennial taxa A. manihot subsp. tetraphyllus var. pungens, the present findings contradict with Hochreutiner (1900), Van Borssum-Waalkes (1966), Paul and Nayar (1988) and Paul (1993) who treat it as a variety of A. manihot subsp. tetraphyllus. In the NJ dendrogram obtained from $52 \times 17$ data matrix, this taxon showed distant position from A. manihot subsp. tetraphyllus var. tetraphyllus and A. manihot subsp. manihot. Vredebregt (1991) also demonstrated that A. manihot subsp. tetraphyllus var. pungens was not much different from var. tetraphyllus. In contrast, A. manihot subsp. tetraphyllus var. pungens was the only taxon which showed triangular hilum when it was rounded in A. manihot subsp. tetraphyllus var. tetraphyllus. Thus, hilum shape played a decisive role in differentiating these two taxa. In view of taxonomic significance, epidermal cell features differentiate A. manihot subsp. tetraphyllus var. pungens from widely distributed A. manihot subsp. tetraphyllus var. tetraphyllus and A. manihot subsp. manihot. Apart from morphological variability in A. manihot complex, species reflected great distinctness in seed micro-morphological characters which implies a need to study the specimens of A. manihot subsp. manihot, A. manihot subsp. tetraphyllus var. tetraphyllus and A. manihot subsp. tetraphyllus var. pungens using advance molecular markers for precise species differentiation and ranking.

The result obtained confirms the usefulness of seed morphology for identification and categorization of sub-specific taxa of A. angulosus. Based on variation in flower color, Sivarajan and Pradeep (1996) defined three varieties of A. angulosus, namely A. angulosus var. grandiflorus (yellow corolla), A. angulosus var. angulosus (white corolla) and A. angulosus var. purpureus 
(pink corolla). The present study significantly provides two more important seed characters which differentiate these varieties: A. angulosus var. grandiflorus (epidermal cell- tetra or pentagonal, elongate), A. angulosus var. angulosus (epidermal cell- polygonal) and A. angulosus var. purpureus (epidermal cell- tetra or pentagonal, not elongate) and therefore, confirm the treatment of Sivarajan and Pradeep (1996). The present study also confirms the uniqueness of recently described A. palianus (Sutar et al., 2013). As observed in NJ tree, A. palianus was found to be closely related to $A$. angulosus.

In conclusion, classical taxonomy i.e. morphological descriptors, floras, type designations, and identification keys are still important and therefore the present study on Abelmoschus provides primary means and promotes further investigations in systematics and genomics.

\section{Acknowledgments}

This work was conducted with funding from National Agriculture Innovation Project of Indian Council of Agriculture Research, Government of India. The facilitation of work by Director, NBPGR, New Delhi is duly acknowledged.

\section{References}

Adanson, M. 1763. Familles des Plantes, Partie I., Paris.

Bates, D.M. 1968. Notes on the cultivated Malvaceae. 2, Abelmoschus. Baileya 16: 99-112.

Bisht, I.S., Patel, D.P., Mahajan, R.K., Koppar, M.N., Thomas, T.A. and Rana, R.S. 1995. Catalogue of wild Abelmoschus species germplasm, NBPGR, New Delhi.

Bisht, I.S., Patel, D.P., Mahajan, R.K., Koppar, M.N., Thomas, T.A. and Rana, R.S. 1993. Catalogue on okra [A. esculentus (L.) Moench] germplasm. Part III, NBPGR, New Delhi.

Edlley, M.P., Marccus, A., Anderson, A.A., Clarisse, P.S. and Fabio, P. 2012. Integrating different tools to disentangle species complexes: A case study in Epidendrum (Orchidaceae). Taxon 61: 721-734.

Godfray, H.C.J. 2002. Challenges for taxonomy. Nature 417: 17-19.

Hamon, S. and Charrier, A. 1983. Large variation of okra collected in Benin and Togo. Plant Genetic Resources Newsletter 56: 52-58.

Hochreutiner, B.P.G. 1900. Revision du genre Hibiscus. Conservatoire et Jardin Botaniques Gene've. Annuarie 4: 23-191.

Hochreutiner, B.P.G. 1924. Genres nouveaux et genres discutes de la famille des Malcacees, Candollea 2 : 79-90.

John, K.J., Scariah, S., Nissar, V.A., Bhat, K.V. and Yadav, S.R. 2012. Abelmoschus enbeepeegearense sp. nov. (Malvaceae), an endemic species of okra from Western Ghats, India. Nord. J. Bot. 30: 1-6.

Joshi, A.B., Gadwal, V.R. and Hardas, M.W. 1974. Evolutionary studies in world crops. In: Hutchinson, J.B. (Ed.), Diversity and Change in the Indian Sub-Continent. Cambridge University Press, London, pp. 99 105.

Masters, M.T. 1874. Malvaceae. In: Hooker, J.D. (Ed.), Flora of British India, Vol. 1, London, pp. 317-353.

Masters, M.T. 1875. Flora of British India, Ashford Kent. Hooker, J.D. (Ed.) 1: 320-348.

Medikus, F.K. 1787. UebereinigekunstlicheGeschlechteraus der Malvenfamilie, den der Klasse der, Monadelphien. 45-46.

Otte, D. and Endler, J.A. 1989. Speciation and its consequences: Sunderland, Massachusetts: Sinauer Associates, pp. 28-59.

Patil, P., Malik, S.K., Sutar, S., John, J., Yadav, S. and Bhat, K.V. 2015. Taxonomic importance of seed macro- and micro-morphology in Abelmoschus Medik. (Malvaceae). Nord. J. Bot., DOI: 10.1111/njb.00771.

Paul, T. and Nayar, M.P. 1988. Malvaceae. Flora of India, Fascicle 19: 61-73.

Paul, T.K. 1993. Malvaceae. In: Sharma, B.D. and Sanjappa, M. (Eds), Flora of India, Vol. 3, Calcutta, pp. 257-394.

Rohlf, F.J. 1992. NTSYS-PC: Numerical taxonomy and multivariate analysis system, version 2.0. Stony Brook: State University of New York. 
Sandhu, G.S., Sharma, B.R., Singh, B. and Bhalla, J.S. 1974. Sources of resistance to jassids and white fly in okra germplasm. Crop Impr. 1: 77-81.

Sivarajan, V.V. and Pradeep, A.K. 1996. Malvaceae of Southern Peninsular India. Daya Pub. House, Delhi, India, pp. 44-73.

Sokal, R. and Sneath, P.H. 1963. Principles of Numerical Taxonomy. W.H. Freeman, San Francisco, 359 pp.

Sunday, E.A., Ariyo, O.J. and Robert, L. 2008. Genetic relationships among West African okra (Abelmoschus caillei) and Asian genotypes (Abelmoschus esculentus) using RAPD. Afr. J. Biotechnol. 7: 1426-1431.

Sutar, S.P., Patil, P., Aitawade, M., John, J., Malik, S., Rao, S., Yadav, S., Bhat, K.V. 2013. A new species of Abelmoschus Medik. (Malvaceae) from Chhattisgarh, India. Genet. Resour. Crop Evol. 60: 1953-1958.

Van Borssum-Waalkes, J. 1966. Malesian Malvaceae Revised. Blumea 14: 89-105.

Vredebregt, J.H. 1991. Taxonomic and ecological observations on species of Abelmoschus Medik. In: Report of an International workshop on Okra Genetic Resources held at NBPGR, New Delhi, India, 8-12 October 1990, pp. 60-76.

(Manuscript received on 13 March 2015; revised on 19 September 2015) 